\title{
Serum from Patients with Type 2 Diabetes with Neuropathy Induces Complement-independent, Calcium-dependent Apoptosis in Cultured Neuronal Cells
}

\author{
Shanthi Srinivasan, ${ }^{*}$ Martin J. Stevens, ${ }^{\ddagger}$ Huaibao Sheng, ${ }^{\star}$ Karen E. Hall, ${ }^{\star}$ and John W. Wiley* \\ $*$ Division of Gastroenterology and ${ }^{\ddagger}$ Division of Endocrinology, Department of Internal Medicine, University of Michigan Medical Center \\ and the Ann Arbor Veterans Affairs Medical Center, Ann Arbor, Michigan 48105
}

\begin{abstract}
We hypothesized that sera from type 2 diabetic patients with neuropathy contains an autoimmune immunoglobulin that promotes complement-independent, calcium-dependent apoptosis in neuronal cell lines. Neuronal cells were cultured in the presence of complement-inactivated sera obtained from patients with type 2 diabetes with and without neuropathy and healthy adult control patients. Serum from diabetic patients with neuropathy was associated with a significantly greater induction of apoptosis, compared to serum from diabetic patients without neuropathy and controls. In the presence of calcium channel antagonists, induction of apoptosis was reduced by $\sim 50 \%$. Pretreatment of neuronal cells with serum from diabetic patients with neuropathy was associated with a significant increase in elevated $\mathrm{K}^{+}$-evoked cytosolic calcium concentration. Serum-induced enhancement in cytosolic calcium and calcium current density was blocked by treatment with trypsin and filtration of the serum using a 100,000-kd molecular weight filter. Treatment with an anti-human IgG antibody was associated with intense fluorescence on the surface of neuronal cells exposed to sera from patients with type 2 diabetes mellitus with neuropathy. We conclude that sera from type 2 diabetic patients with neuropathy contains an autoimmune immunoglobulin that induces complement-independent, calcium-dependent apoptosis in neuronal cells. (J. Clin. Invest. 1998. 102:14541462.) Key words: programmed cell death - serum factors • cell injury • autoimmune $\cdot$ cytosolic calcium
\end{abstract}

\section{Introduction}

Diabetic neuropathy is a common symptomatic complication of diabetes mellitus and encompasses a group of clinical syndromes with manifestations involving somatic and autonomic peripheral nerves. Diabetic neuropathy occurs with the same frequency in type 1 and 2 diabetic patients (1). Peripheral nerve abnormalities in animal and human diabetic patients, such as decreased conduction velocity, axonal swelling, and nerve fiber loss (2-5) have been linked to metabolic alterations

Address all correspondence to John W. Wiley, M.D., Veterans Affairs Medical Center, 2215 Fuller Rd., Rm. B501a, Box 111D, Ann Arbor, MI 48105. Phone: 313-761-7981; FAX: 313-761-7549; E-mail: jwiley@umich.edu

Received for publication 12 January 1998 and accepted in revised form 12 August 1998.

J. Clin. Invest.

(C) The American Society for Clinical Investigation, Inc. 0021-9738/98/10/1454/09 \$2.00

Volume 102, Number 7, October 1998, 1454-1462

http://www.jci.org
(6), including altered calcium signaling (7). Studies involving human and animal models of diabetes indicate that altered cytosolic calcium homeostasis is a common defect in both insulin-dependent and non-insulin-dependent diabetes, resulting in increased cytosolic calcium levels (7-11). Elevation in cytosolic calcium concentration has been linked to apoptosis in a number of experimental models (12-15).

Recent evidence suggests that a serum factor (or factors) may play a role in the pathogenesis of diabetic neuropathy in patients with type 1 diabetes mellitus. Treatment of cultured pancreatic $\beta$-cells with serum from patients with type 1 diabetes mellitus was associated with enhanced L-type calcium currents (16). Exposure of neuroblastoma cells to complement-activated sera from patients with type 1 diabetes with neuropathy was associated with decreased neurite outgrowth, enhancement of calcium influx, and induction of apoptosis (17-19). However, the linkage of enhanced calcium influx and induction of apoptosis was not proven in previous studies $(16,19)$. Furthermore, the potential contribution of autoimmune immunoglobulin(s) and altered calcium signaling in the pathogenesis of neuropathy in type 2 diabetes has not been examined. We observed the presence of an autoimmune immunoglobulin in sera from type 2 diabetic patients with neuropathy that was associated with complement-independent, calcium-dependent induction of apoptosis in vitro in neuronal cell lines.

\section{Methods}

\section{Patient information}

Prior approval for these studies was obtained from the University of Michigan Institutional Review Board. After informed consent was obtained, sera were collected from patients with type 2 diabetes with $\left(\mathrm{DN}^{+}\right)^{1}$ and without $\left(\mathrm{DN}^{-}\right)$neuropathy and healthy adult controls. All patients were recruited from the Michigan Diabetes Research and Training Center Clinical Core at the University of Michigan (Ann Arbor, MI). Data on the sex, weight, hemoglobin $\mathrm{A}_{1 \mathrm{C}}\left(\mathrm{HbA}_{1 \mathrm{C}}\right)$, serum glucose, serum creatinine, duration of diabetes, and neuropathy is presented in Table I. None of the patients had evidence of any other autoimmune diseases. Control patients were free of diabetes, autoimmune disease, and neuropathy. All control studies were performed on the same day as with diabetic patients. The control and diabetic samples were age matched and both stored at $-70^{\circ} \mathrm{C}$ for the same duration of time.

Clinical neuropathy was defined as an abnormal neurological examination that was consistent with the presence of peripheral sensorimotor neuropathy plus either abnormal nerve conduction in at least two peripheral nerves or unequivocally abnormal autonomic nerve testing. Abnormal sensorimotor exam was determined by

1. Abbreviations used in this paper: CAM, cell adhesion molecules; $\mathrm{DN}^{+}$, diabetic patients with neuropathy; $\mathrm{DN}^{-}$, diabetic patients without neuropathy; DRG, dorsal root ganglion; NGF, nerve growth factor; sBP, systolic blood pressure; TUNEL, terminal deoxynucleotidyl transferase-mediated nick end labeling. 
Table I. Demographics and Patient Characteristics of Study Patients

\begin{tabular}{lcc}
\hline & $\mathrm{DN}^{+}$ & $\mathrm{DN}^{-}$ \\
\hline Patients $(n)$ & 10 & 7 \\
Age $(\mathrm{yr})$ & $65 \pm 2.5$ & $67 \pm 6$ \\
Sex $(\%$ female) & 15 & 15 \\
Weight (lbs) & $207 \pm 10$ & $200 \pm 17$ \\
Duration of diabetes $(\mathrm{yr})$ & $21 \pm 3$ & $2.75 \pm 0.5$ \\
Duration of neuropathy $(\mathrm{yr})^{*}$ & $7.7 \pm 1.6$ & $\mathrm{~N} / \mathrm{A}$ \\
HbA $_{1 \mathrm{C}}(\%)$ & $8.4 \pm 0.5$ & $7.4 \pm 0.4$ \\
Serum glucose $(\mathrm{mg} / \mathrm{dl})$ & $222 \pm 2.5$ & $178 \pm 24$ \\
Serum creatinine $(\mathrm{mg} / \mathrm{dl})$ & $1.2 \pm 0.2$ & $1.1 \pm 0.2$ \\
& & \\
\hline
\end{tabular}

*Neuropathy defined by the presence of symptoms and signs of neuropathy and the presence of delayed nerve conduction velocity by electromyogram (Methods, patient data), and/or autonomic neuropathy. N/A: not applicable. All values are $\mathrm{x} \pm$ standard error. Adult control patients had no evidence of diabetes, autoimmune disease, or neuropathy. No significant difference was noted in age, sex, weight, $\mathrm{HbA}_{1 \mathrm{C}}$, or creatinine in $\mathrm{DN}^{+}$versus $\mathrm{DN}^{-}$patients. The duration of diabetes was significantly lower in $\mathrm{DN}^{-}$patients compared to $\mathrm{DN}^{+} . P<0.05$.

screening for symptoms of numbness, burning, pain or cramps in legs or feet, and signs of abnormal sensation (light touch, pain, and vibration), muscle strength, and tendon reflexes in the extremities. Patients with nephropathy and proliferative retinopathy were excluded from the study. Nerve conduction velocities were performed on the nondominant side with the lower limb maintained at $32^{\circ} \mathrm{C}$ and the upper limb at $33^{\circ} \mathrm{C}$. Sural, median, and ulnar sensory-evoked potential amplitudes, and distal and peak latencies were evaluated. The amplitudes of the compound muscle action potentials for the peroneal and median motor nerves and their respective distal latencies and conduction velocities were performed. A nerve was considered abnormal if any attribute (amplitude, distal latency, or conduction velocity) was not within the normal limits, defined as values between the first and 99th percentiles (20). When two or more nerves were abnormal, nerve conduction was considered abnormal.

Autonomic function testing. The resting heart rate was calculated after a period of 20-min supine rest. The heart rate variability response to six deep breaths/min $(5 \mathrm{~s}$ in and $5 \mathrm{~s}$ out $)$ was recorded for 1 min on a continuous electrocardiogram trace. The maximum and minimum R-R intervals during each breathing cycle were measured and converted to beats/min, and a mean value was calculated for the six measured cycles. The heart rate response to the Valsalva maneuver (expiration against a pressure of $40 \mathrm{~mm} \mathrm{Hg}$ for a period of $15 \mathrm{~s}$ ) was performed three times, and a mean value was calculated for the ratio of the longest $\mathrm{R}-\mathrm{R}$ interval after the maneuver to the shortest $\mathrm{R}-\mathrm{R}$ interval during the maneuver. The patient then rested supine for $20 \mathrm{~min}$. After a mean supine systolic blood pressure (sBP) was measured, the patient stood erect, and the sBP was recorded immediately and at 1-min intervals, thereafter, for a further 5-min period. The lowest standing $\mathrm{sBP}$ was recorded, and the $\mathrm{sBP}$ fall calculated. If two of four tests were outside published normal values (21), the patient was considered to have abnormal autonomic function.

\section{Reagents}

DME, Ham's F-12, FBS, penicillin, streptomycin, goat serum, and trypsin were obtained from GIBCO BRL Laboratories (Gaithersburg, MD). 7S-murine nerve growth factor (NGF), aphidocolin, collagenase, trypsin, trypan blue, neural-buffered formalin, RNase, cis-platin, FITC-linked anti-human IgG antibody were obtained from Sigma Chemical Co. (St. Louis, MO). Terminal transferase enzyme, biotin-conjugated dUTP and FITC-avidin, were obtained from
Boehringer Mannheim Biochemical (Indianapolis, IN). Fura-2 acetylmethyl ester and slowfade were obtained from Molecular Probes (Eugene, OR).

\section{Cell cultures}

Studies were performed on two neuronal cell lines, as well as primary sensory neurons (dorsal root ganglion neurons [DRG]), to corroborate our observations in more than one type of neuronal preparation.

SH-SY5Y. The human neuroblastoma cell SH-SY5Y clone was provided by Dr. Martin Stevens, Department of Endocrinology, University of Michigan. The neuronal cells were maintained in $150-\mathrm{cm}^{2}$ Corning T-150 flasks in a 1:1 mixture of DME and Ham's F-12 containing $15 \%$ FBS, penicillin (100 IU/ml), streptomycin $(100 \mu \mathrm{g} / \mathrm{ml}), 2$ $\mathrm{mM}$ L-glutamine, and $15-\mathrm{mm}$ Hepes buffer at $37^{\circ} \mathrm{C}$ with a $10 \% \mathrm{CO}_{2}$ atmosphere. Neuronal cells were detached using Trypsin-EDTA (0.05\% trypsin, $0.53 \mathrm{mM}$ EDTA) for $2 \mathrm{~min}$ at $37^{\circ} \mathrm{C}$ and replated at $10^{6}$ cells $/ 150-\mathrm{cm}^{2}$ flask. Passage number never exceeded 30 .

Cell differentiation. SY5Y cells were exposed to $1 \mu \mathrm{g} / \mathrm{ml} 7 \mathrm{~S}$-murine NGF in the above growth medium, immediately after replating, and the medium was changed every two days for the duration of the culture. Aphidocolin, an inhibitor of a DNA polymerase, was added to the medium in the second week of treatment at $10 \mu \mathrm{g} / \mathrm{ml}$. After $4 \mathrm{wk}$ of differentiation with NGF, the neurons were used in the experiments (22). Differentiated SY5Y neuronal cells were plated at 0.3 million cells per 22-mm coverslip in a $35-\mathrm{mm}$ culture dish. Neuronal cells were cultured in DME/F-12 containing $15 \%$ FCS for $24 \mathrm{~h}$. The medium was removed and washed with PBS and the neuronal cells cultured for $48 \mathrm{~h}$ in DME/F-12 containing $15 \%$ of either control or test serum.

F-11 neuronal cells were maintained at $37^{\circ} \mathrm{C}$ in a humidified atmosphere containing $5 \% \mathrm{CO}_{2} / 95 \%$ air in Ham's F-12 media supplemented with $15 \%$ FCS and penicillin $(100 \mathrm{IU} / \mathrm{ml})$ and streptomycin $(100 \mu \mathrm{g} / \mathrm{ml})(23)$. Media were changed three times per week.

$D R G$ neurons. Isolated, acutely dissociated DRG neurons were aseptically prepared from 3-6-wk Sprague-Dawley rats (Indianapolis, IN). Rats were killed by inhalation of $100 \%$ carbon dioxide, the spinal column removed, and thoracic and lumbar DRGs extracted. DRGs were trimmed, minced, incubated with $0.3 \%$ collagenase and $0.1 \%$ trypsin, and then triturated and centrifuged. Enzymes and incubating media were composed of sterile MEM supplemented with 16 $\mathrm{mM} \mathrm{NaHCO} 2$ and $28 \mathrm{mM}$ D-glucose (320 mosm), and filtered (0.2 $\mu \mathrm{m})$. Isolated DRGs were resuspended in supplemented MEM containing $10 \%$ sera from $\mathrm{DN}^{+}$patients with neuropathy and non-diabetic controls, and plated onto collagen-coated tissue culture dishes. No other sera or growth factors were added to the culture media. Cells were incubated in $93 \%$ air $+7 \% \mathrm{CO}_{2}$ at $37^{\circ} \mathrm{C}$ for $24 \mathrm{~h}(24)$.

\section{Cell viability}

After exposure of SY5Y neuronal cells to medium containing 5-15\% of either control or test serum, cell viability was assessed. Cells were exposed to $0.2 \%$ trypan blue for $10 \mathrm{~min}$ and the number of trypan blue positive cells per 200 cells were counted in a blinded manner (25).

\section{Determination and quantitation of apoptosis}

Apoptosis was detected using the TUNEL (terminal deoxynucleotidyl transferase-mediated dUTP nick end labeling) method, as described below. The morphological characteristics of apoptosis induced by serum was confirmed using electron microscopy.

TUNEL method. SY5Y neuronal cells were cultured for 24-72 h in DME containing $5-15 \%$ of either control or test serum. On a single experimental day, each subject's serum was applied on neurons, and this was performed in duplicate. Neuronal cells were fixed in $4 \%$ neural-buffered formalin for $15 \mathrm{~min}$ followed by methanol for $10 \mathrm{~min}$. Neurons were stored at $-20^{\circ} \mathrm{C}$ for $24 \mathrm{~h}$. Apoptosis was detected using the TUNEL method (26). The test is based on the principle that terminaldeoxynucleotidyl transferase catalyzes a template-independent addition of deoxynucleotides to free $3^{\prime} \mathrm{OH}$ ends present in DNA 
breaks. This tailing reaction is especially sensitive to the type of DNA fragmentation occurring in apoptotic rather than necrotic cell death (27). Coverslips were washed with cold PBS and incubated with biotin-conjugated dUTP and terminal transferase enzyme for $1 \mathrm{~h}$ at $37^{\circ} \mathrm{C}$. After washing, the neurons were incubated with FITC-avidin for $1 \mathrm{~h}$ at room temperature (light protected). The specimens were mounted in slowfade containing $5 \mu \mathrm{g} / \mathrm{ml}$ propidium iodide and 0.05 $\mathrm{mg} / \mathrm{ml}$ Dnase-free Rnase. The FITC-labeled DNA fragments in the apoptotic cells can be visualized using fluorescent microscope. 200 neuronal cells were counted blindly and the positive cells expressed as a percentage of total neurons counted. The percentage of neurons undergoing apoptosis was standardized to the number of neurons attached to the coverslip after exposure to serum for $48 \mathrm{~h}$, followed by fixation and immunohistochemistry using the TUNEL method. This includes adherent early necrotic cells that will stain with propidium iodide but not with the FITC. The number of necrotic neurons was not subtracted from each group before calculating the percent of apoptotic neurons. Negative control received only the label solution without terminal transferase and the positive control had Cisplatin (2 $\mu \mathrm{g} / \mathrm{ml}$ ) in the medium (28). The reliability of the TUNEL method for detection of apoptosis was established in our laboratory using cisplatinum as a positive control for the induction of apoptosis. The sensitivity and specificity of the TUNEL method was confirmed in our system using measurement of neuronal DNA content in conjunction with flow cytometry, and electron microscopy.

Electron microscopy. Differentiated SY5Y neuronal cells were plated on 35-mm dishes and cultured for $1 \mathrm{~d}$ (28). Neuronal cells were exposed to $15 \%$ sera from control or a type 2 diabetic patient with neuropathy for $48 \mathrm{~h}$. The neuronal cells were fixed for $10 \mathrm{~min}$ in $3 \%$ glutaraldehyde in $0.12 \mathrm{M}$ phosphate buffer, $\mathrm{pH} 7.4$, postfixed in $1 \%$ $\mathrm{OsO} 4$ in $0.18 \mathrm{M}$ phosphate buffer for $10 \mathrm{~min}$ at $40^{\circ} \mathrm{C}$, dehydrated in graded alcohols, and embedded in epoxy resin. Thin sections were cut perpendicular to the bottom of the culture dish and stained with uranyl acetate and lead citrate. Sections were examined with a Phillips CM100 transmission electron microscope (Mahwah, NJ) and digitized images were obtained using a Kodak Mega Plus 11.6 camera (Rochester, NY).

\section{Effect of calcium channel antagonists on serum-induced apoptosis}

SY5Y neuronal cells and F-11 neuronal cells were exposed to control or diabetic serum for 24-48 $\mathrm{h}$ in the presence of calcium channel antagonists, $\omega$-conotoxin GVIA ( $N$-type channel antagonist, $100 \mathrm{nM}$ ), and nifedipine (L-type channel antagonist, $10 \mathrm{mM}$ ) at $37^{\circ} \mathrm{C}$. Experiments were performed in the dark to avoid inactivation of nifedepine. After $24-48 \mathrm{~h}$, neuronal cells were fixed and stained for apoptosis by the TUNEL method described above. The number of TUNEL(+) neuronal cells per 200 neurons were counted under fluorescent microscopy. Counting was performed in a blinded manner.

\section{Measurement of calcium}

Calcium measurements were performed using two different techniques: the calcium-sensitive dye Fura-2 to measure cytosolic calcium concentration, and patch-clamp electrophysiology to measure calcium current density.

Cytosolic calcium. Using the Fura-2 technique (29), cytosolic calcium $\left(\left[\mathrm{Ca}^{2+}\right]_{\mathrm{i}}\right)$ concentration was measured in differentiated SY5Y neuronal cells exposed to control, $\mathrm{DN}^{-}$, or $\mathrm{DN}^{+}$serum for $48 \mathrm{~h}$. Coverslips were washed in PBS, and then incubated for $40 \mathrm{~min}$ in culture medium containing 2.5-mM Fura-2 acetylmethyl ester and free acid at $37^{\circ} \mathrm{C}$ in an incubator, and then placed into a perfusion chamber on the stage of an inverted microscope (Nikon Inc., Melville, NY) and superfused continuously with oxygenated Krebs buffer at $37^{\circ} \mathrm{C}$. To avoid any bias due to decreased responsiveness to depolarization in neurons previously depolarized, only one set of neuronal cells was studied on each slip. Fluorescence was elicited by illumination with light wavelengths alternating between 340 and $380 \mathrm{~nm}$ at 0.5 -s intervals. Fluorescence was recorded using a calcium-imaging system
(Zeiss Axiovert; Attaflor Ratiovision, Rockville, MD). The ratio of the signals generated at 340 and $380 \mathrm{~nm}$ was used to calculate $\left[\mathrm{Ca}^{2+}\right]_{\mathrm{i}}$ (nM) by the method of Grynkiewicz et al. (29). Calibration of $\left[\mathrm{Ca}^{2+}\right]_{i}$ was performed according to Gelperin et al. (30). The intracellular calcium is calculated using the formula $\left[\mathrm{Ca}^{2+}\right]_{\mathrm{i}}=\mathrm{K}_{\mathrm{d}}[\mathrm{R}-\mathrm{R}(\mathrm{Lo}) / \mathrm{R}(\mathrm{Hi})-$ $\mathrm{R}] * \operatorname{Den}(\mathrm{Lo}) / \operatorname{Den}(\mathrm{Hi})$ where R: measured 340:380 ratio, $\mathrm{K}_{\mathrm{d}}$ : dissociation constant for the dye, $\mathrm{R}(\mathrm{Lo})$ : ratio for low standard, $\mathrm{R}(\mathrm{Hi})$ : ratio for high standard, Den(Lo): denominator intensity for low standard, and Den(Hi): denominator intensity for high standard. The SY5Y neuronal cells were depolarized with 15 -s applications of elevated $\mathrm{K}^{+}$ buffer $(60 \mathrm{mM} \mathrm{KCl})$. The basal $\left[\mathrm{Ca}^{2+}\right]_{\mathrm{i}}$ and amplitude of peak $\left[\mathrm{Ca}^{2+}\right]_{\mathrm{i}}$ response to depolarization was measured. Acute serum application studies were performed by exposure of SY5Y or F-11 neuronal cells to $1 / 40$ dilution of serum in buffer for $30 \mathrm{~s}$, followed by depolarization with elevated $\mathrm{K}^{+}$buffer for $15 \mathrm{~s}$. Studies done with each subject's sera were repeated twice on two separate experiment days.

Whole-cell voltage-clamp recordings. $24 \mathrm{~h}$ after exposure to control or diabetic sera, whole-cell voltage-clamp recordings were performed on DRG neurons. Isolated, phase-bright DRG neurons 20-40 $\mathrm{mm}$ in diameter were identified and whole-cell voltage-clamp recordings using the whole-cell variant of the patch-clamp technique (31) were made at room temperature. Glass recording patch pipettes (Fisher Microhematocrit tubes; Fisher Scientific Co., Pittsburgh, PA) with electrode resistance 1-2 M $\Omega$, and seal resistances $>1 \mathrm{GV}$ were used. Recordings were made in culture dishes containing nonperfused external bath solution consisting of: $5 \mathrm{mM} \mathrm{CaCl}_{2}, 67 \mathrm{mM}$ choline $\mathrm{Cl}, 100 \mathrm{mM}$ TEA Cl, $5.6 \mathrm{mM}$ glucose, $5.3 \mathrm{mM} \mathrm{KCl}, 10 \mathrm{mM}$ Hepes, and $0.8 \mathrm{mM} \mathrm{Mg}^{2+} \mathrm{Cl}$ ( $\mathrm{pH} 7.4,320-330$ mosmol). Recording electrodes were filled with $140 \mathrm{mM} \mathrm{CsCl}, 10 \mathrm{mM}$ Hepes, $10 \mathrm{mM}$ EGTA, $5 \mathrm{mM} \mathrm{Mg}^{2+}$ ATP, and $0.1 \mathrm{mM} \mathrm{Li} \mathrm{GTP} \mathrm{(pH} \mathrm{7.3-7.4,} \mathrm{280-290}$ mosm). DRGs were depolarized with voltage steps generated by the program CLAMPEX (pCLAMP; Axon Instruments, Foster City, CA). Calcium currents were recorded using an Axopatch 200 A amplifier with an input resistance of 1-3 M $\Omega$, filtered with a Bessel filter $10 \mathrm{kHz}$, sampled at $20 \mathrm{kHz}$, and stored on hard disk. High-threshold currents were evoked in neurons held at $-80 \mathrm{mV}$ by $100 \mathrm{~ms}$ duration depolarizations to $+10 \mathrm{mV}$ every $20 \mathrm{~s}$. Current-voltage (IV) curves were generated by depolarizing neurons from a holding potential of $-80 \mathrm{mV}$ in $10 \mathrm{mV}$ steps for $100 \mathrm{~ms}$ from command potentials of -110 to $180 \mathrm{mV}$. This protocol allowed for examination of the range of activation (from low- to high-threshold) calcium currents.

Analysis of current components. The effect of diabetic sera on high-threshold calcium currents was evaluated. High-threshold currents ( $N$-, L-, P-, and Q-type) are activated by depolarizing the neuron from holding potentials of -80 or $-90 \mathrm{mV}$ to clamp potentials of $+10 \mathrm{mV}$. To normalize currents to size of cell body, whole cell currents were divided by whole cell capacitance. Capacitance traces were elicited by small depolarizing calibration voltage pulses $(+5 \mathrm{mV}$ for $12 \mathrm{~s}$ ) from a holding potential of $-80 \mathrm{mV}$. Whole cell capacitance (proportional to surface area) was calculated from the formula $\mathrm{C}=$ $\mathrm{A} / \mathrm{V}$, where $\mathrm{C}=$ capacitance $(\mathrm{pF}), \mathrm{A}=$ area under the capacitance current curve from the peak inward current to the point at which $\mathrm{I}_{\mathrm{Ca}}=0$ $(\mathrm{pF} / \mathrm{mV})$, and $\mathrm{V}=$ calibration voltage step $(\mathrm{mV})$. Peak inward currents were divided by cell capacitance, and normalized current density expressed in units of $\mathrm{pA} / \mathrm{pF}$.

\section{Serum and drug preparation}

$20 \mathrm{ml}$ of serum obtained from patients were stored in aliquots at $-70^{\circ} \mathrm{C}$. Complement was heat inactivated by heating serum in a water bath at $56^{\circ} \mathrm{C}$ for $40 \mathrm{~min}$. $\Omega$-Conotoxin $(\omega$-conotoxin GVIA, $\omega$-cgTx) $1 \mathrm{mM}$ stock solution (Sigma Chemical Co.) was prepared with filtered distilled water and lyophilized in $10 \mathrm{ml}$ aliquots, and then stored at $-20^{\circ} \mathrm{C}$. On the experimental day, $100 \mathrm{nM} \omega$-cgTx was prepared in the culture media. Nifedipine $(100 \mathrm{mM})$ solution in DMSO was prepared fresh on the experimental day and diluted 1:10,000 in culture medium. The solution was protected from light throughout the experiment. 


\section{Characterization of serum factor}

Studies were performed to determine whether the serum factor associated with increased calcium influx was trypsin sensitive and possessed a molecular weight $>100,000 \mathrm{kd}$. Complement-inactivated serum samples from controls and diabetic patients were treated with trypsin $(0.005 \%)$ and, subsequently, evaluated for their effect on elevated $\mathrm{K}^{+}$-evoked cytosolic calcium concentration. In separate studies, sera from control and diabetic patients were passed through molecular sizing filters (Amicon, Beverly, MA) that trap substances with a molecular weight $>100,000 \mathrm{kd}$. Subsequently, the effect of the residue $(>100,000 \mathrm{kd})$ and filtrate $(<100,000 \mathrm{kd})$ on elevated $\mathrm{K}^{+}$evoked cytosolic calcium concentration was evaluated.

To confirm the presence of an autoimmune immunoglobulin in diabetic serum, sera from control and diabetic patients were tested for binding to the surface membrane of SY5Y neuronal cells by immunocytochemistry (18). SY5Y neuronal cells were plated on coverslips coated with Matrigel and cultured for $24 \mathrm{~h}$. The cells were washed with PBS and fixed in $4 \%$ paraformaldehyde in PBS for 30 $\mathrm{min}$ at $4^{\circ} \mathrm{C}$. Cells were exposed to $10 \% \mathrm{vol} / \mathrm{vol}$ goat serum in PBS for $30 \mathrm{~min}$, and then incubated with complement-inactivated serum obtained from control, $\mathrm{DN}^{+}$, or $\mathrm{DN}^{-}$patients $(10 \% \mathrm{vol} / \mathrm{vol})$ for $90 \mathrm{~min}$. Finally, neuronal cells were incubated with FITC-linked anti-human IgG antibody (1:64 dilution), (Sigma Chemical Co.) for $60 \mathrm{~min}$. The coverslips were washed with PBS for $5 \mathrm{~min}$, three times after each step. All incubations were performed at room temperature. Coverslips were mounted on a glass slide using a glycerol-based mounting medium. Images were obtained on a MRC-600 Biorad Confocal microscope (Hercules, CA) using a $60 \times$ oil immersion lens. The fluorescent intensity of the microscope was calibrated before each experiment to minimize interrun variability. Calibration of the confocal microscope was done using the InSpecK fluorescent microscope image intensity calibration kit (Molecular Probes). The microscope is calibrated with fluorescent bead standards that do not vary in intensity.

\section{Statistical analysis}

The data are summarized as the mean \pm standard error. Statistical analysis was performed using one-way ANOVA with appropriate adjustment for nonparametric statistics. All statistics were done using the InSTAT software program. Statistical significance was accepted at the $P<0.05$ level.

\section{Results}

Patient profile. Adult control patients had no evidence of diabetes, autoimmune disease, or neuropathy. 7 non-diabetic adult controls, $10 \mathrm{DN}^{+}$patients, and $7 \mathrm{DN}^{-}$patients were studied. No significant difference was present in age, sex, weight, $\mathrm{HbA}_{1 \mathrm{C}}$, or creatinine in $\mathrm{DN}^{+}$versus $\mathrm{DN}^{-}$patients $(P>0.05)$. The duration of diabetes was significantly lower in $\mathrm{DN}^{-}$patients compared to $\mathrm{DN}^{+}$patients, $P<0.05$ (Table I).

Exposure of SY5Y neuronal cells to sera from $\mathrm{DN}^{+}$patients was associated with induction of apoptosis. Sera from $\mathrm{DN}^{+}$patients were associated with a significantly greater induction of apoptosis $\left(7.37 \pm 2.4 \%, n=10\right.$ patients) compared to $\mathrm{DN}^{-}$ $(1.02 \pm 0.3 \%, n=7$ patients, $P<0.05)$ and non-diabetic control sera $(0.8 \pm 0.25 \%, n=7$ patients, $P<0.05)$ (Fig. $1, A$ and $C)$ patients. Statistical analysis was performed using non-parametric one-way ANOVA. Experiments using sera from each subject were repeated twice on two separate experimental days. On each experimental day, a subject's serum was evaluated in duplicate cultures. For each subject, the percentage of apoptosis represents the mean of apoptosis on different experimental days.
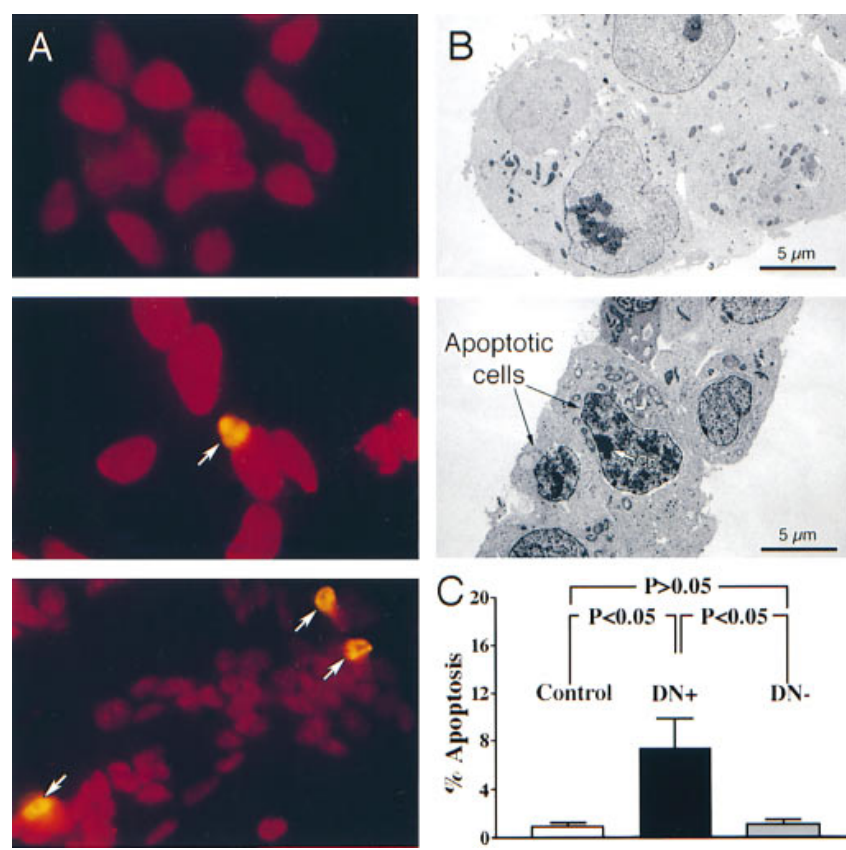

Figure 1. Apoptosis in SY5Y neuronal cells. $(A)$ Representative photographs of SY5Y neuronal cells stained for apoptosis using the TUNEL method. (Top) Neuronal cells grown in culture medium supplemented with non-diabetic control serum $(15 \%, 48 \mathrm{~h})$. (Center) Neuronal cells grown in culture medium supplemented with serum obtained from a $\mathrm{DN}^{+}$patient $(15 \%, 48 \mathrm{~h})$. (Bottom) Positive control: neuronal cells cultured in the presence of media containing FCS and cis-platin $(2 \mu \mathrm{g} / \mathrm{ml}, 48 \mathrm{~h}) .60 \times$. Arrows point to TUNEL + apoptotic cells. $(B)$ Transmission electron micrographs of differentiated SY5Y neuronal cells cultured in the presence of (upper) non-diabetic control serum and (lower) serum obtained from a $\mathrm{DN}^{+}$patient $(15 \%$, $48 \mathrm{~h}$ ). Arrows point to the apoptotic cells demonstrating chromatin condensation $(\mathrm{Ch})$, preservation of mitochondria, and plasma membrane. $(C)$ Neuronal cells were cultured in the presence of human serum obtained from $\mathrm{DN}^{+}$and $\mathrm{DN}^{-}$patients and non-diabetic control patients. The mean \pm SEM percent of apoptosis in neuronal cells in the presence of sera from non-diabetic controls, $\mathrm{DN}^{+}$and $\mathrm{DN}^{-}$patients is shown.

Electron microscopy. Serum from one $\mathrm{DN}^{+}$patient known to induce apoptosis by the TUNEL method was used to confirm apoptosis by electron microscopy based on the morphological characteristics. SY5Y neuronal cells, cultured in the presence of serum from the $\mathrm{DN}^{+}$patient but not control serum, demonstrated the characteristic chromatin condensation and preservation of mitochondria and plasma membrane observed in apoptosis (32). In neuronal cells exposed to non-diabetic control sera, 0/52 neuronal cells demonstrated apoptosis, whereas $4 / 38(10.5 \%)$ demonstrated apoptosis after exposure to serum from the $\mathrm{DN}^{+}$patient $($Fig. $1 B$ ).

Necrosis. The percentage of necrotic neurons was similar after exposure to sera from $\mathrm{DN}^{+}(21 \pm 4 \%$ in SY $5 Y$ neuronal cells, $6.25 \pm 1.7$ in F-11 neuronal cells, $n=6$ patients) compared to sera from controls $(16 \pm 3.8 \%$ in SY5Y neuronal cells, $6 \pm 0.03$ in F-11 neurons, $n=6$ patients, $P=0.4$ in SY5Y neuronal cells and $P=0.9$ in F-11 neuronal cells).

Exposure of neurons to sera from $D N^{+}$patients enhanced calcium influx. Experiments were performed using separate neuronal preparations exposed to control, $\mathrm{DN}^{+}$, and $\mathrm{DN}^{-}$sera on a particular experimental day. Repeated measurements in 
neuronal cells on the same day exposed to one serum sample revealed that the data were highly reproducible. Because the day to day variability in neuronal cytosolic calcium responses was relatively high, $(109 \pm 40 \mathrm{nM})$, compared to the variability recorded on the same day $(39 \pm 5 \mathrm{nM})$, the responses to $\mathrm{DN}^{+}$ and $\mathrm{DN}^{-}$sera were expressed as a percentage increase over the response to control serum, recorded on the same day. Basal and peak cytosolic calcium response for $\mathrm{DN}^{+}$and $\mathrm{DN}^{-}$ serum was expressed as the percentage increase over basal and peak responses to control serum. Statistical analysis of the effect of control, $\mathrm{DN}^{+}$, and $\mathrm{DN}^{-}$sera on cytosolic calcium levels was performed using one-way ANOVA and $(n)$ as the number of subjects tested. Sera from $\mathrm{DN}^{+}$patients caused a significant enhancement $(143 \pm 10 \%$ increase, $n=5$ patients, average 23 neurons with each serum, $P=0.01)$ in elevated $\mathrm{K}^{+}(60 \mathrm{mM}$, $15 \mathrm{~s}$ )-evoked cytosolic calcium levels compared to the calcium levels observed after exposure to control sera ( $n=5$ subjects, average 16 neurons each). Serum from $\mathrm{DN}^{-}$patients was not associated with calcium enhancement compared to controls ( $73 \pm 16 \%$ of control serum, $n=3$ patients, 5 neurons evaluated with each serum, $P=0.3$ ) (Fig. $2, A-C$ ). Short-term (30 s) exposure of SY5Y neuronal cells and F-11 neuronal cells to sera from $\mathrm{DN}^{+}(n=2,1: 40$ dilution) before depolarization with elevated $\mathrm{K}^{+}(60 \mathrm{mM}, 15 \mathrm{~s})$ significantly enhanced cytosolic calcium $(680 \pm 5 \%$ increase compared to neuronal cells exposed to non-diabetic control sera, $n=60$ neuronal cells, $P=$ 0.0001). The effect of exposure to sera from diabetics with neuropathy was concentration-dependent, as enhancement in
A

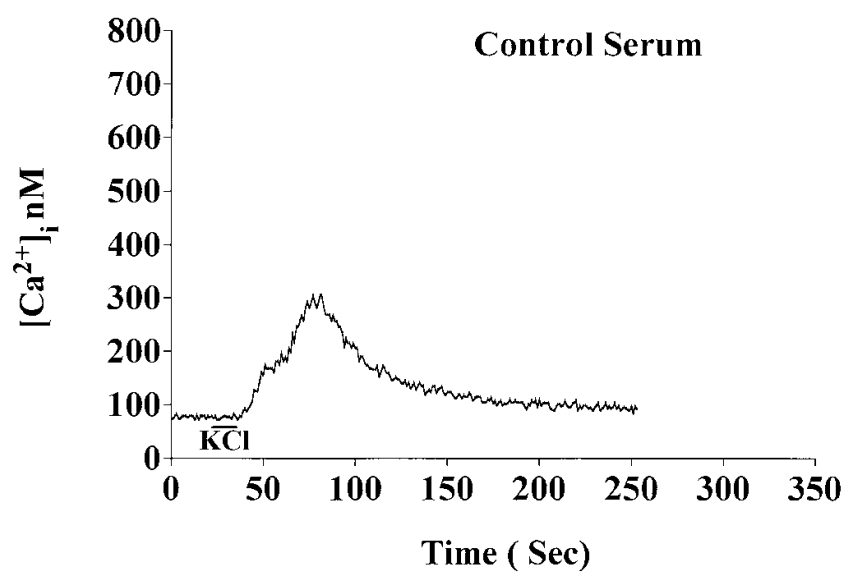

C

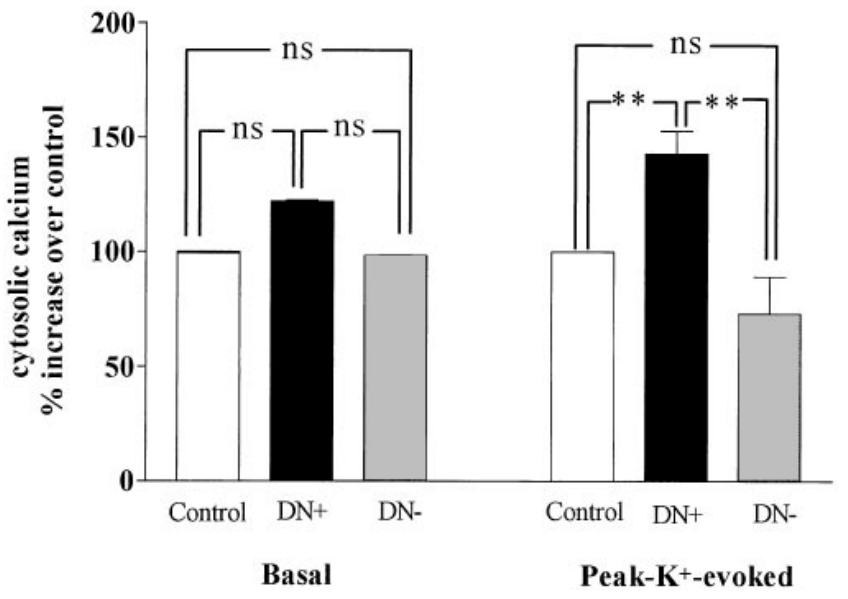

B

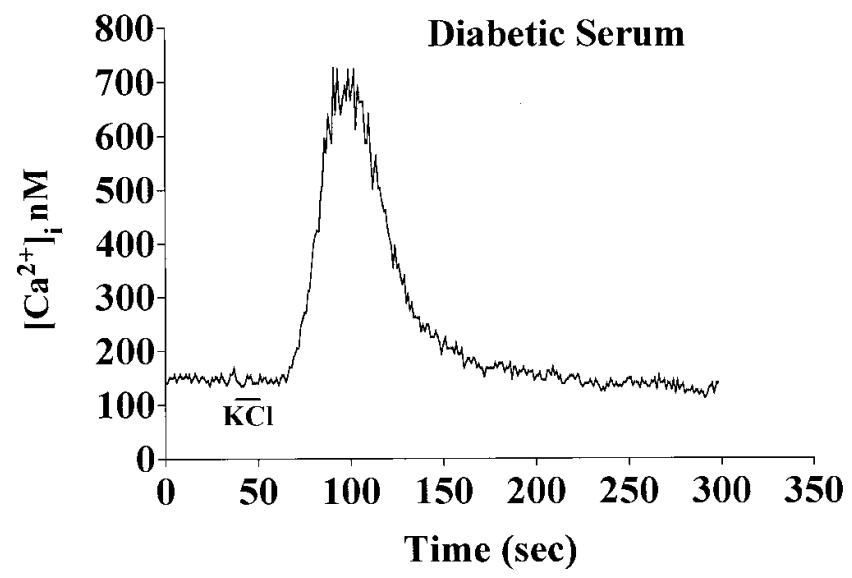

D

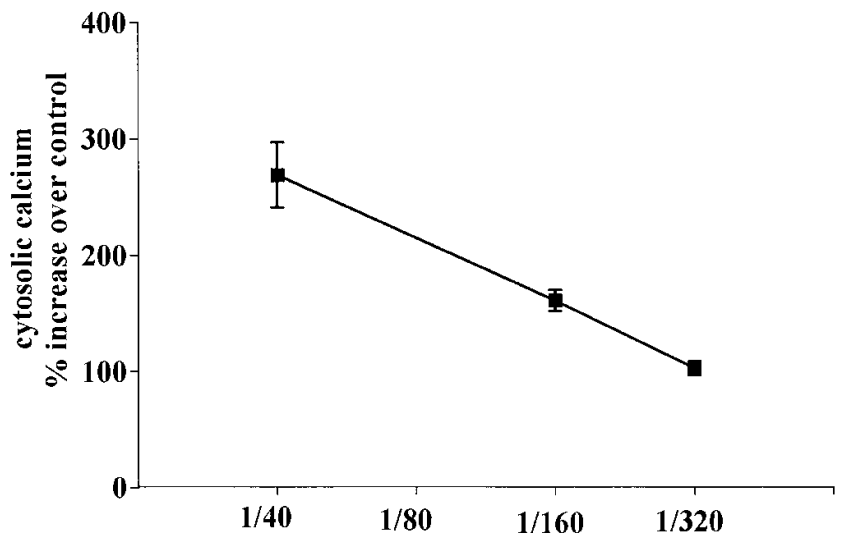

Serial dilution of serum from a DN+ subject (dilution in PBS)

Figure 2. $(A$ and $B)$ Cytosolic calcium $\left(\left[\mathrm{Ca}^{2+}\right]_{\mathrm{i}}\right)$ response in differentiated SY5Y neuronal cells. Representative tracings of elevated $\mathrm{K}^{+}(60$ $\mathrm{mM})$-evoked cytosolic calcium $\left(\left[\mathrm{Ca}^{2+}\right]_{\mathrm{i}}\right)$ response in differentiated SY5Y neuronal cells, cultured in the presence of serum for $48 \mathrm{~h}$, from either control subjects $(A)$ or $\mathrm{DN}^{+}$patients $(B)$. $(C)$ Basal and elevated $\mathrm{K}^{+}(60 \mathrm{mM}, 15 \mathrm{~s})$-evoked cytosolic calcium recorded in differentiated SY5Y neuronal cells in the presence of serum from non-diabetic controls, $\mathrm{DN}^{+}$patients, and $\mathrm{DN}^{-}$patients. Results expressed as a percentage of calcium level recorded after exposure to non-diabetic control serum. $* * P=0.01$. (D) Dilution-response curve of $\left[\mathrm{Ca}^{2+}\right]_{\mathrm{i}}$ response in F-11 neurons exposed to serum from a $\mathrm{DN}^{+}$patient applied for $30 \mathrm{~s}$. Results are expressed as a percentage increase in cytosolic calcium concentration compared to control serum. Serial dilution attenuated the cytosolic calcium response to the $\mathrm{DN}^{+}$serum in PBS. 
cytosolic calcium was observed at dilutions up to 1 in 1,000 , $n=3$ (Fig. $2 D$ ).

Exposure of neurons to serum from $\mathrm{DN}^{+}$patients was associated with enhanced calcium current density

We confirmed $\mathrm{DN}^{+}$serum-mediated enhancement in calcium influx electrophysiologically. Peak calcium current density recorded from DRG neurons exposed to serum from a $\mathrm{DN}^{+}$patient known to enhance cytosolic calcium was significantly higher $(687 \pm 121 \mathrm{pA} / \mathrm{pF}, n=3$ neurons $)$ compared to treatment of neurons with sera from non-diabetic controls $(227 \pm 42$, $\mathrm{pA} / \mathrm{pF}, n=$ total of 9 neurons using sera from three controls). The calcium current density in neurons exposed to serum from a $\mathrm{DN}^{+}$patient was $>95 \%$ confidence intervals for the nondiabetic controls. Statistical analysis was performed using oneway ANOVA, using $n$ as the number of neuronal cells.

Combination of $N$ - and L-type calcium channel antagonists attenuated the effect of sera from $D N^{+}$patients on apoptosis

We next evaluated the effect of sera from $\mathrm{DN}^{+}$patients on apoptosis in the presence and absence of calcium channel antagonists. In the presence of $\mathrm{N}$ - and L-type calcium channel antagonists, induction of apoptosis was significantly decreased (50 $\pm 17 \%$ reduction, $n=4$ patients, $P=0.03$ ) (Fig. 3 ).

\section{Characterization of serum factor}

The sera from two $\mathrm{DN}^{+}$patients known to enhance cytosolic calcium and two controls were used to study the effect of trypsin and filtration on serum-induced cytosolic calcium enhancement. Our initial studies indicated that the diabetic serum-mediated enhancement in calcium influx was abolished after treatment with trypsin. The peak in elevated $\mathrm{K}^{+}(60$ $\mathrm{mM}$ )-evoked $\left[\mathrm{Ca}^{2+}\right]_{\mathrm{i}}$ in neuronal cells exposed to sera from $\mathrm{DN}^{+}$patients was $618 \pm 23 \mathrm{nM}$. After treatment with trypsin, the $\left[\mathrm{Ca}^{2+}\right]_{\mathrm{i}}$ response decreased to $298 \pm 22 \mathrm{nM}$ ( $n=67$ neu-

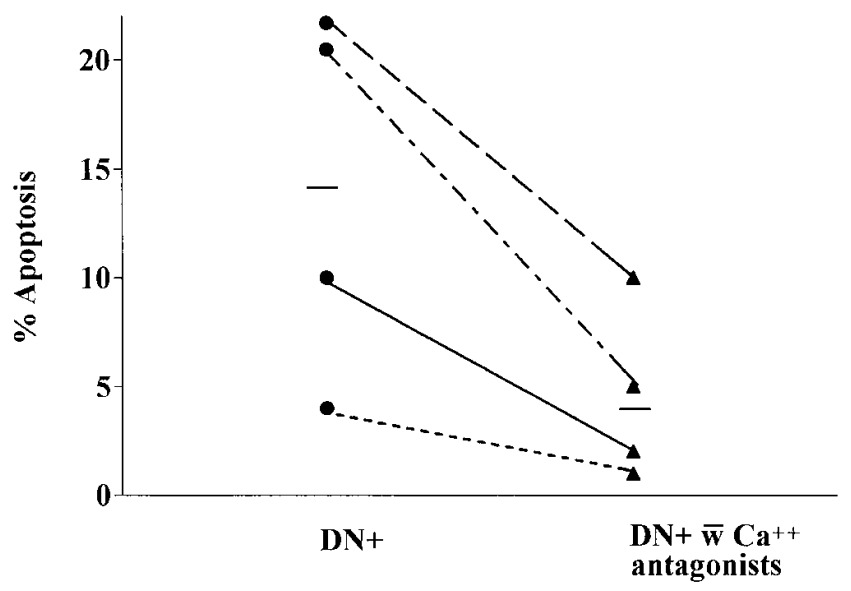

Figure 3. Effect of calcium channel antagonists on diabetic seruminduced apoptosis. Differentiated SY5Y neuronal cells were exposed to non-diabetic control or $\mathrm{DN}^{+}$sera for $48 \mathrm{~h}$ in the presence of calcium channel antagonists, $\omega$-conotoxin GVIA (100 nM, N-type calcium channel antagonist), and nifedipine (10 mM L-type calcium channel antagonist). In the presence of $\mathrm{N}$ - and L- type calcium channel antagonists, induction of apoptosis by $\mathrm{DN}^{+}$serum was significantly reduced. Each line represents apoptosis induced by serum from a $\mathrm{DN}^{+}$patient in the absence (solid circle) and presence (solid triangle) of calcium channel antagonist. The mean is denoted by a horizontal bar. ronal cells, $n=2$ patients, $P<0.002$ ) (Fig. $4 A$ ). Exposure of neuronal cells to trypsin alone did not affect serial depolarizations with elevated $\mathrm{K}^{+}$. Passing the sera through a molecular weight sizing filter revealed that the serum factor associated with enhanced calcium influx was located predominately in the residue, e.g., $>100,000 \mathrm{kd}$. Elevated $\mathrm{K}^{+}$-evoked $\left[\mathrm{Ca}^{2+}\right]_{\mathrm{i}}$ response in the presence of reconstituted residue (1:40 dilution) from control sera was $924 \pm 143 \mathrm{nM}$, whereas the residue from $\mathrm{DN}^{+}$sera was $1263 \pm 78 \mathrm{nM}, n=15$ neuronal cells, $P=0.04$. The $\left[\mathrm{Ca}^{2+}\right]_{\mathrm{i}}$ response to control filtrate $(\mathrm{MW}<100,000 \mathrm{kd})$ was $473 \pm 35 \mathrm{nM}$ and $\mathrm{DN}^{+}$filtrate $488 \pm 36 \mathrm{nM},(n=15 \mathrm{neu}-$ ronal cells, not significant) (Fig. $4 \mathrm{~B}$ ). The calcium current density in DRG neurons exposed to the $\mathrm{DN}^{+}$residue (retained $85 \%$ of original activity) was significantly larger than the current density observed in neurons exposed to the $\mathrm{DN}^{+}$filtrate (retained $51 \%$ of activity) (Fig. $4 C$ ). Statistical analysis was performed using one-way ANOVA, using $n$ as the neuronal cells. These studies suggested that the serum factor was a large molecular weight protein, possibly an immunoglobulin.

We next examined whether exposure of SY5Y neuronal cells to $\mathrm{DN}^{+}$serum known to induce apoptosis and enhance neuronal calcium was associated with the presence of autoimmune immunoglobulin(s) directed against autoantigens on the surface membrane. Minimal fluorescence was observed in SY5Y neuronal cells exposed to control sera and, subsequently, evaluated for the presence of immunoglobulins in the IgG class. In contrast, neuronal cells exposed to the serum from the $\mathrm{DN}^{+}$patient demonstrated intense fluorescence on the cell surface membrane (Fig. 5). The average pixel intensity in neuronal cells exposed to the serum from the $\mathrm{DN}^{+}$patient was significantly larger compared to sera from $\mathrm{DN}^{-}$and control patients, (controls: $108 \pm 6$ pixels $/ \mathrm{mm}^{2}, n=32$ neuronal cells using sera from two subjects; $\mathrm{DN}^{-}$patients: $134 \pm 6$ pixels/ $\mathrm{mm}^{2}, n=36$ neuronal cells using sera from two patients; $\mathrm{DN}^{+}$ patient: $173 \pm 7$ pixels $/ \mathrm{mm}^{2}, n=23$ neuronal cells, $P<0.001$ ) (Fig. 5). Statistical analysis was performed using one-way ANOVA.

\section{Discussion}

Autoimmune immunoglobulins have been identified in type 2 diabetes mellitus $(33,34)$, but their involvement in the pathophysiology of diabetic neuropathy has not been examined. Our studies support the presence of immunoglobulins in sera from $\mathrm{DN}^{+}$patients that was associated with complement-independent, calcium-dependent induction of apoptosis. We believe that these are the first studies to demonstrate calcium-dependent apoptosis induced by serum from type 2 diabetic patients. Sera from $\mathrm{DN}^{+}$patients caused a ninefold increase in apoptosis compared to non-diabetic control sera. The induction of apoptosis by sera from $\mathrm{DN}^{+}$patients may have clinical significance, as long-term exposure of nerves to serum in vivo could contribute to the development of neuropathy. Under our culture conditions, SY5Y neuronal cells had a reproducibly low rate of baseline apoptosis $(>1 \%)$, which allowed us to readily detect differences in apoptosis in response to exposure to sera from controls and diabetics. The range of induction of apoptosis by sera from $\mathrm{DN}^{+}$patients varied from $0-21 \%$. Of the 10 patients who demonstrated a significant increase in apoptosis, cytosolic calcium responses were recorded using sera from five patients. Sera that were the most potent in inducing apoptosis were used to examine the effect of calcium channel antagonists and 


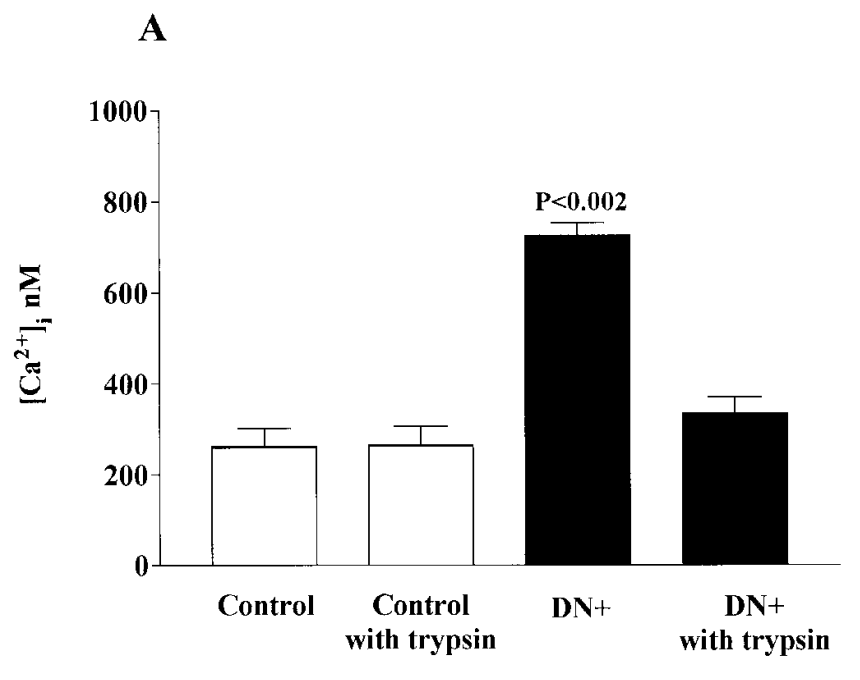

B

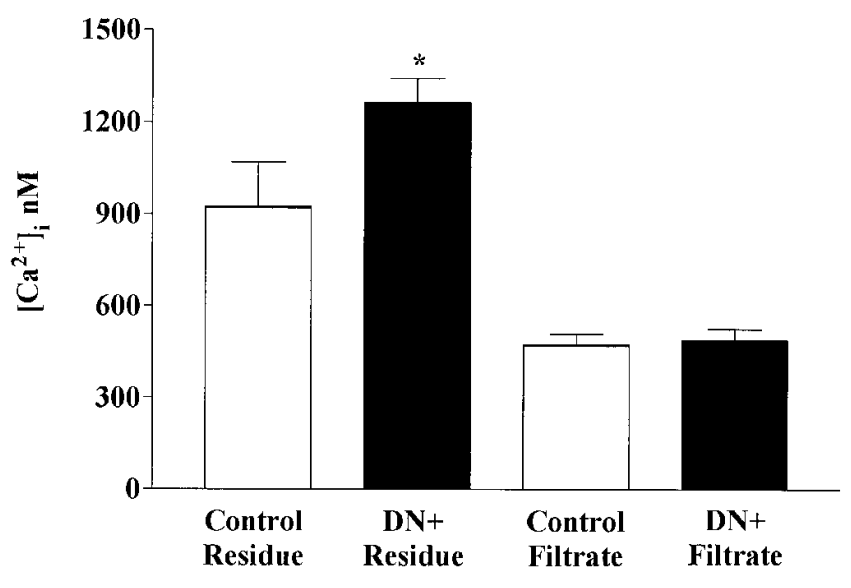

C

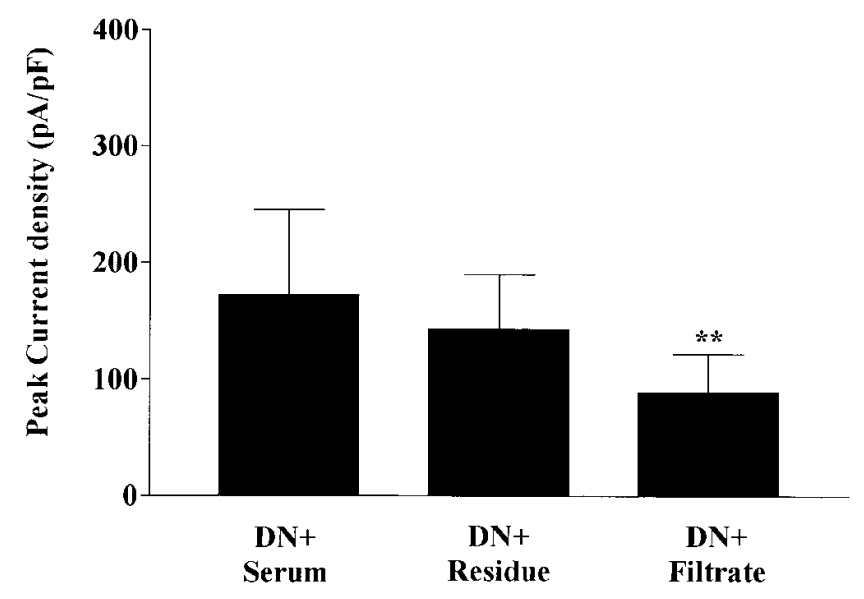

Figure 4. Characterization of serum factors. $(A)$ Elevated $\mathrm{K}^{+}$-evoked cytosolic calcium response in neuronal cells exposed to $\mathrm{DN}^{+}$serum was $618 \pm 23 \mathrm{nM}$. After treating the $\mathrm{DN}^{+}$sera with trypsin, the $\mathrm{K}^{+}$evoked $\left[\mathrm{Ca}^{2+}\right]_{\mathrm{i}}$ response decreased to $298 \pm 22 \mathrm{nM}, n=67$ neurons, $P<$ 0.002 . Numbers 1 and 2 represent sera from two $\mathrm{DN}^{+}$patients. The peak elevated $\mathrm{K}^{+}$-evoked $\left[\mathrm{Ca}^{2+}\right]_{\mathrm{i}}$ response is depicted before and after treatment with trypsin. (B) Calcium current density in DRG neu-

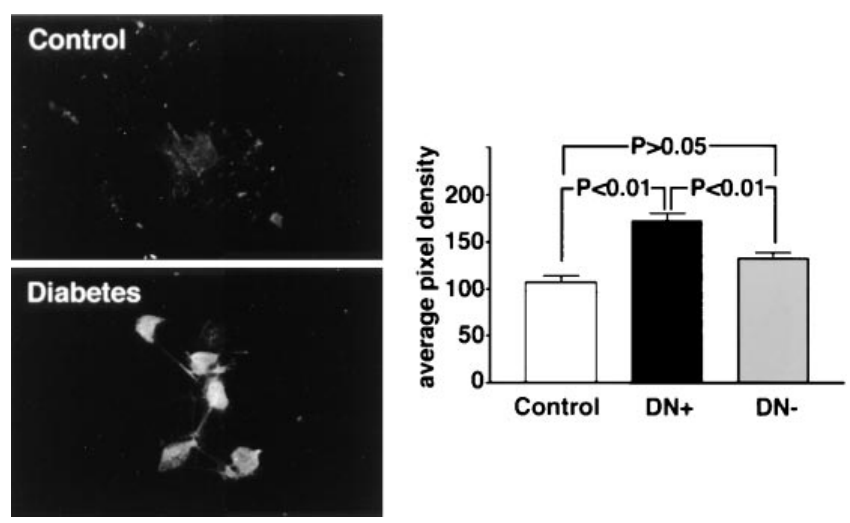

Figure 5. Immunofluorescence images of SY5Y neuronal cells using confocal microscopy. (Left) Representative immunofluorescence images of SY5Y neuronal cells exposed to sera from controls and $\mathrm{DN}^{+}$ patients and, subsequently, evaluated for the presence of immunoglobulins (IgG class) by indirect immunofluorescence using confocal microscopy $\left(60 \times\right.$ lens). Neuronal cells exposed to serum from $\mathrm{DN}^{+}$ patients demonstrated intense fluorescence on the surface membrane that was not observed in neurons exposed to sera from controls.

(Right) SY5Y neuronal cells exposed to sera from controls, $\mathrm{DN}^{+}$, and $\mathrm{DN}^{-}$patients and, subsequently, evaluated for the presence of immunoglobulins (IgG class) by indirect immunofluorescence using confocal microscopy. The average pixel intensity in neuronal cells exposed to $\mathrm{DN}^{+}$serum was significantly higher compared to sera from $\mathrm{DN}^{-}$ and control subjects.

to further characterize serum factors. We used a variety of methods using two neuronal cell lines, as well as primary sensory neurons, to corroborate our observations on calcium signaling and induction of apoptosis.

The relative inability of sera from $\mathrm{DN}^{-}$patients to either induce apoptosis or enhance cytosolic calcium response to depolarization supports the hypothesis that serum factors play a pathophysiological role in neuropathy independent of hyperglycemia. We believe that serum-induced apoptosis was not due to hyperglycemia, per se, as the glucose concentration of the medium $(20 \mathrm{mM})$ precluded a significant effect of the serum glucose concentration after a fivefold dilution. Other studies have demonstrated that physiological concentrations of glucose had no effect on free intracellular calcium in PC12 cells and a fourfold elevation of glucose above physiological levels reduced calcium influx (35). The data obtained using sera from patients with diabetes without neuropathy provide some insight regarding the pathophysiology of the autoimmune mechanisms in type 2 patients. These individuals had diabetes mellitus for shorter duration (2.75 \pm 0.5 compared to $21 \pm 3 \mathrm{yr}$ ), demonstrated an intensity of anti-IgG immunofluorescence

rons exposed to serum from a $\mathrm{DN}^{+}$patient passed through a 100,000 molecular weight filter. The residue $(>100,000 \mathrm{kd})$ retained the ability to enhance calcium currents, whereas the filtrate $(<100,000 \mathrm{kd})$ lost this ability. (C) Elevated $\mathrm{K}^{+}$-evoked cytosolic calcium in the presence of reconstituted serum residue $(>100,000 \mathrm{kd}, 1: 40)$ from a control and $\mathrm{DN}^{+}$patient. The $\mathrm{K}^{+}$-evoked $\left[\mathrm{Ca}^{2+}\right]_{\mathrm{i}}$ response was significantly greater in the presence of the residue from a $\mathrm{DN}^{+}$patient compared to the residue from a non-diabetic control. The filtrate $(<100,000 \mathrm{kd})$ from the control and $\mathrm{DN}^{+}$patient did not cause enhancement of the elevated $\mathrm{K}^{+}$-evoked $\left[\mathrm{Ca}^{2+}\right]_{\mathrm{i}}$ response. 
that was intermediate to non-diabetic controls and diabetics with neuropathy, and did not demonstrate a significant increase in either cytosolic calcium levels or apoptosis compared to non-diabetic controls. These results suggest that the development of autoantibodies in diabetes may precede abnormalities in calcium signaling and apoptosis. The range of apoptosis observed in the $\mathrm{DN}^{+}$group is consistent with heterogeneous expression of the proposed mediator(s) of this process. Future studies will be required to identify, quantify, and correlate potential relationships between the duration of diabetes, titer of autoimmune immunoglobulin, enhancement in cytosolic calcium, and induction in apoptosis. The effect appeared to be selective for apoptosis as necrosis rates were not different. Both short-term ( $30 \mathrm{~s})$ and long-term $(48 \mathrm{~h})$ exposure of neurons to serum from $\mathrm{DN}^{+}$patients enhanced elevated $\mathrm{K}^{+}$-evoked cytosolic calcium response. Evaluation of whether distinct signal transduction pathways are involved in the calcium elevation in these two models will be the subject of future studies.

Juntti-Berggren et al. (16) demonstrated enhanced calcium currents (L-type) in pancreatic $\beta$-cells exposed to sera from newly diagnosed patients with type 1 diabetes. They postulated that the factor in diabetic sera was an immunoglobulin. Pittinger et al. (17-19) reported that exposure of neuroblastoma cultures to complement-activated serum from type 1 diabetics with neuropathy was associated with neuronal injury, apoptosis, and enhanced calcium influx. The cause-effect relationship between increased cytosolic calcium and apoptosis was not tested in previous studies. Pittinger et al. (17-19) suggested that the serum factor was an autoimmune immunoglobulin (most likely a complement-fixing $\mathrm{IgG}$ ). Our study design used heat-inactivated sera to eliminate the effect of complement-induced cell death.

We used a combination of $\mathrm{N}$ - and L-type calcium channel antagonists to inhibit influx of calcium into the neurons. SY5Y neuronal cells have multiple voltage-gated calcium channels, and the majority $(>70 \%)$ of calcium influx is via $\mathrm{N}$ - and L-type channels. Therefore, we used a combination of $\mathrm{N}$ - and L-type calcium antagonists (36). We observed $\sim 50 \%$ reduction in apoptosis, indicating that the pathway underlying $\mathrm{DN}^{+}$ serum-induced apoptosis is most likely calcium dependent. Enhancement of multiple neuronal calcium currents in diabetes (8) provides an explanation for the limited improvement in nerve conduction velocity observed in diabetic rats after treatment with a selective L-type calcium channel antagonist $(11,37)$.

Considerable evidence suggests that metabolic overstimulation by cytosolic calcium may contribute to neuronal cell injury and apoptosis (12-14). Internucleosomal DNA cleavage by a $\mathrm{Ca}^{2+}$ and $\mathrm{Mg}^{2+}$-dependent endonuclease, activated by intranuclear $\mathrm{Ca}^{2+}$ uptake, is a characteristic of programmed cell death. Furthermore, the cellular threshold for apoptosis is highly regulated, especially by the members of the Bcl-2 family of proteins, including Bcl-2, Bax, and Bcl-x (38). Serum from type 2 diabetic patients may induce apoptosis via modulating expression of the $\mathrm{Bcl}$ family of proteins (39). In mammalian cells, the cell surface receptor Fas (APO-1, CD-95) induces apoptosis when multimerized with Fas ligand (40). Therefore, activation of Fas may contribute to diabetic serum-induced apoptosis.

The target of the immunoglobulins is not known, although studies with type 1 serum suggest Fas. Several autoantigens have been proposed as possible sites for the targeting of autoimmune immunoglobulins in diabetes mellitus, including phospholipids (41), gangliosides (42), and glutamic acid decarboxylase (43). Other potential targets are cell adhesion molecules (CAMs) of the immunoglobulin superfamily. CAMs (including neural CAM and myelin-associated glycoprotein) have immunoglobulin folds in their extracellular domains (44) and are important in the myelination of axons $(45,46)$. The autoantigen(s) in human type 2 diabetes have not been characterized. It remains to be resolved whether autoimmune immunoglobu$\operatorname{lin}(\mathrm{s})$ are directly or indirectly involved in the pathophysiology of diabetic neuropathy.

In summary, our studies suggest that patients with type 2 diabetes with neuropathy are at risk for generating an autoimmune immunoglobulin associated with enhanced calcium influx and induction of apoptosis in neurons. Attenuation of serum-mediated apoptosis by calcium channel antagonists suggests that the mechanism is calcium dependent. Initial characterization indicates that the serum factor is trypsin sensitive, has a molecular weight $>100,000 \mathrm{kd}$, and enhances calcium influx at dilutions up to 1:1,000, suggesting that the substance is most likely an immunoglobulin. Immunofluorescence studies demonstrated the presence of an (IgG class) immunoglobulin in sera from type 2 diabetic patients with neuropathy. Because sera were heat inactivated, neither the action of the immunoglobulin(s) to increase calcium influx nor the ability to bind neuronal surface membrane autoantigenic sites required complement-fixation. These studies do not rule out the possibility that additional immunoglobulins will be identified in sera from type 2 diabetic patients with neuropathy. The presence of autoimmune immunoglobulin(s) in the serum of type 2 diabetic patients may represent a new risk factor for the development of diabetic neuropathy.

\section{Acknowledgments}

The authors would like to thank Brenda Vibbart for her help with typing the manuscript.

\section{References}

1. Greene, D.A., A.A.F. Sima, M.J. Stevens, E.L. Feldman, and S.A. Lattimer. 1992. Complications: neuropathy, pathogenic considerations. Diabetes Care. 15:1902-1906.

2. Bischoff, A. 1973. Ultrastructural pathology of peripheral nervous system in early diabetes. In Vascular and Neurological Changes in Early Diabetes. R.A. Camerini-Davales and H.S. Cole, editors. Academic Press, New York. 441-449.

3. Behse, F., F. Butchal, and F. Carlsen. 1977. Nerve biopsy and conduction studies in diabetic neuropathy. J. Neurol. Neurosurg. Psych. 40:1072-1082.

4. Brismar, T. 1983. Diabetic neuropathy: functional abnormalities in the BB rat. Metab. Clin. Exp. 32:112-117.

5. Sima, A.A.F., and T. Brismar. 1985. Reversible diabetic nerve dysfunction: structural correlates to electrophysiologic abnormalities. Ann. Neurol. 18: 21-29.

6. Greene, D.A., S.A. Lattimer, and A.A.F. Sima. 1988. Are disturbances of sorbitol, phosphoinositide, and $\mathrm{Na}^{+} \mathrm{K}^{+}$ATpase regulation involved in the pathogenesis of diabetic neuropathy? Diabetes. 37:688-693.

7. Levy, J., J. Gavin, and J. Sowers. 1994. Diabetes mellitus: a disease of abnormal cellular calcium metabolism. Am. J. Med. 96:260-273.

8. Hall, K.E., A.A.F. Sima, and J.W. Wiley. 1995. Voltage dependent calcium currents are enhanced in rat dorsal root ganglion neurons from the Bio/ Bred Worcester diabetic rat. J. Physiol. (Lond.). 486:313-322.

9. Nobe, S., M.A. Aomine, S. Ito, and R. Takaki. 1990. Chronic diabetes mellitus prolongs action potential duration of rat ventricular muscles: circumstantial evidence for impaired $\mathrm{Ca}^{2+}$ channel. Cardiovasc. Res. 24:381.

10. White, R.E., and G.O. Carrier. 1990. Vascular contraction induced by activation of membrane calcium ion channels is enhanced in streptozocin diabetes. J. Pharmacol. Exp. Ther. 253:1057-1062.

11. Kappelle, A.C., B. Bravenboer, J. Traber, D.W. Erkelens, and W.H. 
Gispen. 1992. The $\mathrm{Ca}^{2+}$ antagonist nimodipine counteracts the onset of an experimental neuropathy in streptozotocin-induced diabetic rats. Br. J. Pharmacol. 111:887-893.

12. Trump, B.F., and I. Berezesky. 1995. Calcium-mediated cell injury and cell death. FASEB (Fed. Am. Soc. Exp. Biol.) J. 9:219-228.

13. Dowd, D. 1995. Calcium regulation of apoptosis. Phosphoprotein Res. 30:255-280.

14. Joseph, R., W. Li, and E. Han. 1993. Neuronal death, cytoplasmic calcium and internucleosomal DNA fragmentation: evidence for DNA fragments being released from cells. Mol. Brain Res. 17:70-76.

15. Zhivotovsky, B., D. Wade, and O. Nicotera. 1994. Role of nucleases in apoptosis. Int. Arch. Allergy Immunol. 105:333-338.

16. Juntti-Berggren, L., O. Larsson, P. Rorsman, K. Bokvist, K. Wahlander, P. Nicotera, J. Dypbukt, S. Orrenius, A. Hallberg, and P. Berggrenn. 1993. Increased activity of L-type $\mathrm{Ca}^{2+}$ channels with Type I Diabetes. Science. 261:86-89.

17. Pittinger, G.L., and A.I. Vinik. 1993. The toxic effects of serum from patients with Type 1 Diabetes mellitus on mouse neuroblastoma cells: a new mechanism for the development of diabetic autonomic neuropathy. Diabetic Med. 10:925-932.

18. Pittinger, G.L., and A.I. Vinik. 1995. The neuronal toxic factor in serum of Type 1 diabetic patients is a complement-fixing autoantibody. Diabetic Med. $12: 380-386$.

19. Pittinger, G.L., D. Liu, and A.I. Vinik. 1997. The apoptotic death of neuroblastoma cells caused by serum from patients with insulin-dependent diabetes and neuropathy may be Fas-mediated. J. Neuroimmunol. 76:153-160.

20. Ewing, D.J., and B.F. Clarke. 1982. Diagnosis and management of diabetic autonomic neuropathy. Br. Med. J. 385:916-918.

21. Kimura, J. 1983. Principles of nerve conduction studies. In Electrodiagnosis in Diseases of Nerve and Muscle: Principles and Practice. F.A. Davis Co., Philadelphia, PA. 83-104.

22. Jenson, L. 1987. Phenotypic differentiation of Aphidocolin-selected human neuroblastoma cultures long term exposure to nerve growth factor. Dev. Biol. 120:56-64.

23. Linnik, M.D., H.D. Hatfield, M.D. Swope, and N.K. Ahmed. 1993. Induction of programmed cell death in a dorsal root ganglion $\mathrm{X}$ neuroblastoma cell line. J. Neurobiol. 24:433-446.

24. Hall, K.E., A. Sima, and J.W. Wiley. 1996. Opiate-mediated inhibition of calcium signaling is decreased in dorsal root ganglion neurons from the diabetic BB/W rat. J. Clin. Invest. 97:1165-1172.

25. Patterson, M.K. 1979. Measurement of growth and viability of cells in culture. Methods Enzymol. 58:141-152.

26. Shibaski, F., and F. Mckeon. 1995. Calcineurin functions in $\mathrm{Ca}^{2+}$-activated cell death in mammalian cells. J. Cell Biol. 131:735-743.

27. Gold, R., M. Schmied, G. Giegerich, H. Breitschopf, H.P. Hartung, K.V. Tokya, and H. Lassmann. 1994. Differentiation between cellular apoptosis and necrosis by the combined use of in situ tailing and nick translation techniques. Lab. Invest. 71:219-225.

28. Cece, R., I. Barajon, and G. Tredici. 1995. Cis-platin induces apoptosis in SH-SY5Y human neuroblastoma cell line. Anticancer Res. 15:777-782.

29. Grynkiewics, G., M. Poenie, and R. Tsein. 1985. A new generation of
$\mathrm{Ca}^{2+}$ indicators with greatly improved fluorescent properties. J. Biol. Chem. 260:3440-3450.

30. Gelperin, D., D. Mann, J. DelValle, and J.W. Wiley. 1994. Bradykinin (Bk) increases cytosolic calcium in cultured rat myenteric neurons via Bk-2 type receptors coupled to mobilization of extracellular and intracellular sources of calcium: evidence that calcium influx is prostaglandin dependent. J. Pharma col. Exp. Ther. 271:507-514.

31. Hamill, O.P., A. Marty, E. Neher, B. Sakmann, and F.J. Sigworth. 1981 Improved patch-clamp techniques for high resolution current recording from cells and cell-free membrane patches. Pflugers Arch. 391:85-100. 378.

32. Bär, P.R. 1996. Apoptosis-The cell's silent exit. Life Sciences. 59:369-

33. Sundkvist, G.P. Lind, B. Bergstrom, B. Lilja, and S.L. Rabinowe. 1991. Autonomic nerve antibodies and autonomic nerve function in type 1 and 2 diabetic patients. J. Intern. Med. 229:505-510.

34. Cachia, M.J., M. Peakman, M. Zanone, P.J. Watkins, and D. Vergani. 1997. Reproducibility and persistance of neural and adrenal autoantibodies in diabetic autonomic neuropathy. Diabetes Med.14:461-465.

35. Chang, J., and D.A. Greenberg. 1991. Effects of glucose on calcium channels in neural cells. Neurosci. Lett. 121:34-36.

36. Morton, A.J., C. Hammond, W.T. Mason, and G. Henderson. 1992. Characterization of the L- and N-type calcium channels in differentiated $\mathrm{SH}-$ SY5Y neuroblastoma cells: calcium imaging and single channel recording. Brain Res. Mol. Brain Res. 13:53-61.

37. Ristic, H., J.W. Wiley, K.E. Hall, and A.A. Sima. 1996. Failure of nimodipine to prevent or correct the long-term nerve conduction defect and increased neuronal calcium currents in the diabetic BB/W rat. Diabetes Res. Clin. Prac. 32:135-140.

38. Grajewski, T.F., and C.B. Thompson. 1996. Apoptosis meets signal transduction: elimination of a BAD influence. Cell. 87:589-592.

39. Giordano, C., G. Stassi, M. Todaro, R. De Maria, P. Richiusa, A. Scorsone, M. Giordano, and A. Galluzzo. 1995. Low bcl-2 expression and increased spontaneous apoptosis in T-lymphocytes from newly-diagnosed IDDM patients. Diabetologia. 38:953-958.

40. Nagata, S. 1997. Apoptosis by death factor. Cell. 88:355-365.

41. McNeil, H.P., C.N. Chesterman, and S.A. Krilis. 1991. Immunology and clinical importance of antiphospholipid antibodies. Adv. Immunol. 49:193-280.

42. Nayak, R.C., M.A.K. Omar, A. Rabizadeh, S. Srikanta, and G.S. Eisenbarth. 1985. Cytoplasmic islet-cell antibodies: evidence that the target antigen is a sialoglyco-conjugate. Diabetes. 34:614-619.

43. Ellis, T.M., and M.A. Atkinson. 1996. The clinical significance of an autoimmune response against glutamic acid decarboxylase. Nat. Med. 2:148-153.

44. Williams, A.F., and A.N. Barclay. 1988. The immunoglobulin superfamily domains for cell surface recognition. Ann. Rev. Immunol. 6:381-405.

45. Seilheimer, B., E. Persohn, and M. Schachne. 1989. Antibodies to the L1 adhesion molecule inhibit schwann cell ensheathment of neurons in vitro (part 1). J. Cell Biol. 109:3095-3103.

46. Fruittiger, M., D. Montag, M. Schachner, and R. Martini. 1995. Crucial role for the myelin-associated glycoproteins in the maintenance of axon-myelin integrity. Eur. J. Neurosci. 7:511-515. 